\title{
Herbs of Our Own Kingdom: Layers of the 'Local' in the Materia Medica of Early Chosŏn Korea
}

\author{
Soyoung Suh
}

\begin{abstract}
Previous scholarship takes increasing Korean interest in 'local botanicals' (鄉藥) in its dynamic with Chinese counterparts as a gauge to measure the degree of independence and the extent of indigenisation of Korean medicine during the Choson Dynasty (1392-1910). Questioning this fundamental assumption about the development of Korean medicine, my article aims to scrutinise evocation of 'the local' in changing medical strategies concerned with Korean identity. While analysing major texts on local botanicals published during the early Choson Dynasty, I claim that the classificatory arrangement used to map the local on botanicals often overlapped, and was not organised into a clear set of categories. Considering the traffic of herbal medicine across political and geographical boundaries, and the extreme diversity of botanical names, shapes and attributes, texts on local botanicals cannot be said to show clearly what belongs to a local 'us' or a foreign 'them'. Instead, adjusting the names of botanicals, textualising the folk names of certain species, and publishing a series of books focusing on local botanicals reflected the socio-cultural need of scholars during the Chosŏn Dynasty to imprint motifs of the 'local' on materia medica simultaneously making a display of a separate Korean cultural identity. It was an accommodation of what was regarded as universal knowledge to a locale where the body of Chinese medicine had to be interpreted and mediated by the socio-cultural conditions of Chosŏn Korea.
\end{abstract}

\section{Keywords}

Korean medicine, transcultural studies, materia medica

Celebrating indigenous medicines, or 'our own herb', is not a uniquely Korean phenomenon. Early modern Europe's enthusiasm for exploring local flora was associated with Europe's response to the influx of exotic entities from other lands. The idea of 'indigenous' was invented rather than discovered, as a way of taming botanical entities with foreign origins. The dichotomy of 'indigenous vs. exotic' was first debated and then stabilised while serving as a framework through which the local natural world was documented, legitimised and glorified. The growing interest elaborated upon European local environments exemplifies how the claim of 'our own herb' was intertwined with the creation of regional and cultural identities. ${ }^{1}$

${ }^{1}$ Cooper 2007, pp. 1-50. 
Documenting local botanicals is a complex affair that often involves local actors and social networks. In eighteenth-century Canton, China, garden flowers, fruits and vegetables displayed economic value as exotic goods, hence British merchants and their metropolitan correspondents collected and exported species to London. This process not only depended on British sailors and naturalists but also included local Chinese merchants, indigenous gardens, and Chinese artists for plant illustration. Depicting Canton as a 'contact zone', Fati Fan shows how local plants both as commodities and objects of natural history connected local agents with a broader network of trade and science. ${ }^{2}$

Botanical enterprises across regions, however, were not always successful. Different ideas about the 'indigenous' decided the success or failure of the European documentation of exotic plants. Nicolas L'Emperur, trained in medicine and a long-time resident in Orissa, on the east coast of India, completed his ambitious compilation, Jardin de Loxica, which was composed of a 14-volume folio on herbs. This project clearly relies on the knowledge and experience of local fakirs, merchants and craftsmen. Contrary to L'Emperur's expectation, his ambitious project was not able to gain support from his colleague in Paris, Antony de Jussieu, a member of the Académie des Sciences and professor of botany at the Jardin du Roi. Why did Jussieu refuse to support L'Emperur's grandiose project of documenting Indian materia medica? Jussieu thought that exotic plants in their raw forms had nothing to do with European innovations in medicine. In other words, foreign botanicals that were not appropriately registered with European knowledge of medicine were useless. While L'Emperur thought a more detailed and direct description of the exotic botanicals would pay off for Europeans, Jussieu questioned the underlying assumption of defining the authentic nature of the indigenous. Consequently, Jussieu's comparatively superior position left L'Emperur's Jardin de Loxica in anonymity for centuries. ${ }^{3}$

As the foregoing examples in seventeenth-century Europe, Canton China and South Asia reveal, defining local botanicals across linguistic, cultural and geographic boundaries confirms the inventive nature of 'our own herb'. The idea of the indigenous is never self-evident, demanding a vehicle through which particular attributes of botanicals are related to a broader network of knowledge and trade. An isolated locality, no matter how unusual and promising, hardly gains a name and recognition. In this article, the possibility of using different representations of the 'local' as a medium, or a tool to relate

\footnotetext{
2 Fan 2004, pp. 11-57.
}

3 Raj 2007, pp. 27-59. 
places, their products, and their name to a broader intellectual framework, sheds light on interpreting the Korean longing for 'our own herbs'.

\section{Korean Ginseng}

The story of ginseng best represents the Korean desire to define 'our own herb'. The History of Korean Ginseng (韓國人薪史) proudly states that 'Korean ginseng (高麗人苶) is not merely a commercial good produced in Korea, but a valuable herb in which is embedded the spiritual heritage of our own nation'. ${ }^{4}$ Revised and enlarged in 2002 with handwritten endorsements by the prime minister and the minister of agriculture and forestry, the History of Korean Ginseng attempts to demonstrate Korea's unique place in cultivating and trading ginseng in an ever-growing global market. Contemporary Korean narrative argues that ginseng is grown in many regions and has been a major part of Korean herb consumption for more than two thousand years. Folk stories, poems and local rituals elaborate how Koreans experienced ginseng's divine attributes and marvellous efficacy. Korean envoys to Ming (明, 1368-1644) and Qing (淸, 1644-1912) China and delegations to Tokugawa Japan (德川時代, 1603-1868) provided official and non-official ginseng trade routes in East Asia. ${ }^{5}$ As one of the most profitable herbs, ginseng has been a major source of revenue since the eighteenth century. ${ }^{6}$ Given this commercial and cultural significance, no other herbs match ginseng in conveying the quintessence of Korea.

Running contrary to the Korean desire to identify ginseng as home-grown is the complete absence of the name 'Korean ginseng' as a textual label. First and foremost, modern science does not recognise 'Korean ginseng' as a species. As a common name, 'Korean ginseng' is surely circulated. However, no botanical database, such as the 'Global Biodiversity Information Portal' or the 'Integrated Taxonomic Information System', differentiates Korean ginseng from its Chinese counterpart. ${ }^{7}$ Under the Araliaceace family, Panax ginseng C. Meyer and Panax quinquiefolius are most well-known species for their

\footnotetext{
${ }^{4}$ Han'guk insamsa pyŏnch'an wiwŏnhoe 2002, p. 58.

5 Regarding Japanese interest in Korean ginseng, see Cha 2005.

${ }^{6}$ For details about the Korean understanding of ginseng, see Han'guk insamsa pyŏnch'an wiwŏnhoe 2002. Not much research about Korean ginseng is available in English. Interesting reports about contemporary Korean trade and research are provided by Johannsen 2006, pp. 64$72,173-5$, but no reference is documented here. Many researchers refer to Imamura Tomo's extensive work on ginseng in East Asia. See Imamura 1934. For Korean criticism of Imamura’s work, see Yang and Yeo 2003.

7 See http://data.gbif.org and http://www.itis.gov (Last accessed 31 May 2009).
} 
different tastes and medical efficacy and stand for 'Chinese ginseng' and 'North American ginseng', respectively. As Linda Barnes points out, ginseng has been a part of Western medical trade with China since the seventeenth century. ${ }^{8}$ Ginseng thus gained its name and significance primarily through the commercial and intellectual interaction between 'China and the West'. Korea is marginal in this framework.

The non-existence of 'Korean ginseng' as documented nomenclature is further demonstrated in the textual tradition of Chinese materia medica (本草). Li Shizhen (李時珍, 1518-93), in his Compendium of Materia Medica (本草綱目, 1578), explained ginseng by primarily referring to Tao Hongjing's (陶弘景, 456-536) Collected Commentaries on Classical Materia Medica of the Heavenly Husbandman (本草經集註, c. 530-557). Tao's and Li's accounts recognised regional varieties of ginseng with dozens of place names, including Korean dynasties' names such as 'Silla' (新羅), 'Paekje' (百濟), and 'Koryŏ' (高麗). ${ }^{9}$ No category for coherently acknowledging the Korean origin of ginseng was introduced. This lack of differentiation continued when Zhao Xuemin (趙學敏, 1719-1805) likened ginseng's diversity to newly-recognised place-names of his time. For instance, Zhao's Textual Traces of Compendium of Materia Medica (本草綱目拾遺, 1871) used labels such as tongyang to indicate ginseng from Japan (東洋參), xiyang from France (西洋參), and luofu from today's Guangdong (羅浮參), yet no further inquiry into 'Korean ginseng' was documented..$^{10}$

Given the obscurity of 'Korea ginseng' as a textual label, how do we read this Korean longing for 'our own herb'? Does 'Korean ginseng' merely reflect a contemporary nationalist pride? Or do strategies for making this herb indigenous reveal Korean agency both as a producer and a consumer of medical knowledge at the cultural and political margins of a Sino-centric world order? The process of textualising 'local botanicals' (Hyangyak, 墽藥) in pre-modern Korea provides a locus to consider these questions. ${ }^{11}$

Local botanicals are significant in the history of Korean medicine as they have served as one clear example of indigenisation. For instance, both Miki

${ }^{8}$ Barnes 2007, pp. 52, 105-6, 174-9.

${ }^{9}$ Li Shizhen 1977, Compendium of Materia Medica (本草綱目), juan 12 (renshen, jijie).

${ }^{10}$ Zhao Xuemin 1983, Textual Traces of Compendium of Materia Medica (本草綱目拾遺), juan 3 (caobushang). I thank Carla Nappi for introducing me to Zhao's description of ginseng and sharing her idea about botanicals' 'locality' during the Ming-Qing Dynasties. I also thank participants at a panel titled 'Local Motion: Placing Herbal Knowledge in Early Modern East and Southeast Asia', held at the Annual Meeting of the Association for Asian Studies in Chicago, 26 March 2009.

11 'Hyang' was used to primarily indicate a local town, countryside or administrative unit, such as 'local army' (鄉軍), 'local academy' (鄉校), and 'local clergy' (鄉吏). With the character yak (藥), 'hyangyak' implies 'Korean' or 'native' botanicals as opposed to 'Chinese' (唐藥). 
Sakae (三木榮, 1903-92) and Kim Tu-jong (金斗鍾, 1896-1988), who have provided foundational narratives on the history of Korean medicine from antiquity to the twentieth century, underscored the rise and fall of local botanicals and took them up as a gauge for measuring the degree of independence and the extent of indigenisation of Korean medicine. Miki has argued that the 'independence of medicine' (醫療の自主性) and the 'uniqueness of medicine on the peninsula' (牛島固有の醫學) were both at stake, based on the notion that the native attributes of local botanicals portray the unique features of Korean medicine. ${ }^{12}$ Local botanicals hence play a significant role in understanding what has been regarded as 'Korean' about Korean medicine.

The idea of uniquely Korean attributes of medicine, however, needs rethinking. Partly due to the hierarchical notion of 'Sinicisation', which reduces the heterogeneity of non-Han culture in East Asia to 'Little Chinas' or 'Little Chinese', ${ }^{13}$ and partly due to the colonial vestiges of Japanese scholarship, Korean historians have attempted to recover Korean tradition from earlier accounts that draw the history of medicine in Korea into a grand Chinese narrative. Although this revision serves the contemporary desire to establish a national tradition well, the emphasis on Korean uniqueness has no audience outside Korea. ${ }^{14}$ In addition, a nation-centred unit of analysis often overlooks inter-regional and trans-national flows of medicine, which consist of complex syncretism, contingent changes, and the historical invention of medical traditions in East Asia.

By reconsidering the twentieth century Korean desire to impose national boundaries on medicine and its limitations, this article aims to read the indigenous claim of medicine as an expression of Korean agency at the margins. How did Koreans define indigenous herbs, thereby justifying a Korean realm of medical learning? How did Koreans assess herbs from China, and what justification was made when experts, herbs and Chinese medicine texts authorised the limit of medical innovation in pre-modern Korea? Pondering these questions, this article examines the way in which local botanicals were defined

12 Miki 1963, p. 127. Miki's text includes lengthy quotations from many primary sources, thus providing one of the most substantial accounts of Korean medicine, both chronologically and in its range and variety of topics. No research after Miki can afford to ignore Miki's arguments. I also take Miki's work as a starting point for the discussion of existing scholarship on local botanicals (鄉藥) in Korea, and scrutinise the primary sources and line of arguments Miki set out. All translation, unless otherwise mentioned, is my own. Studies on local botanicals have also been provided by Kim 1966, Kwŏn 1986, and Kim 2001. Kim Tu-jong's and Kim Sin-gŭn's work also includes many excerpts from primary sources. Ahn 2001 and Mun 2006 provide recent perspectives on issues regarding local botanicals.

13 Elman, Duncan and Ooms (eds) 2002, pp. 1-29; Lewis and Wigen 1997, pp. 131-3.

14 Palais 1995, pp. 413-14; Kim Yung Sik 1998. 
and textualised over time. I view local botanicals not as an icon of 'Koreanness' in medicine but as a historically employed tool used in cultures of consumption, which were indispensable to the people who were situated at the margins of a Sino-centric world order. They also provide evidence of an accommodation of what had been regarded as universal to a locale where the body of Chinese medicine had to be interpreted and mediated by the socio-cultural condition of Chosǒn (朝鮮, 1392-1910) Korea.

\section{Local Botanicals in Circulation}

Naming Herbs before the Koryŏ Dynasty (高麗, 918-1392)

Data on botanicals in Korea and their local attributes were first found in the records of the Silla Kingdom (新羅-668 ACE). ${ }^{15}$ A few records scattered in the Koryŏ (高麗, 918-1392) court's History of the Three Kingdoms (三國史記, c. 1145) and Memorabilia of the Three Kingdoms (三國遺史, c. 1281-3) inform us that even before the Koryŏ Dynasty, medical texts from Sui (隋, 581-618) and Tang (唐, 618-907) China were introduced to Korea and referred to as reliable documents in understanding materia medica. For instance, Tao Hongjing's (陶弘景, 456-536) Collected Commentaries on Classical Materia Medica of the Heavenly Husbandman (本草經集註, c. 530-57, hereafter Collected Commentaries) was transmitted to Korea during the Three Kingdoms period (Koguryŏ, Paekche, Silla, c. 313-668); Newly Improved Materia Medica (新修本草, 659) was selected and used as a textbook with the different title of The Canon of Materia Medica (本草經) during the Unified Silla period (統一 新羅, 668-918); and Textual Traces of Materia Medica (本草拾遺, 739) was known to people in the Unified Silla Dynasty. ${ }^{16}$ Today it is almost impossible to know the true extent to which Chinese texts circulated in Silla, nevertheless medical texts, materia medica, and even famous medical practitioners moved between Silla and the Chinese territories. ${ }^{17}$

One of the most noticeable aspects of this traffic was the trade in herbs. History of the Three Kingdoms records Korean tributary offering of ginseng (人蓼) and ox gallstone (牛黃). Most ginseng from Silla was valued as high quality, as evidenced in comments in Liu Yu (陸才才)'s Canon of Tea (茶經,

\footnotetext{
15 Silla was one of the three kingdoms in Korea up to 668. This is called the Three Kingdoms period (Koguryŏ, Paekche, Silla), and Silla exerted its sovereignty upon the southeastern part of Korea, the present-day Kyŏngsang province (慶何道). Lee 1984, pp. 36-65.

${ }^{16}$ For bibliographical information on Chinese Bencao (本草) texts, see Zhuang 1983.

${ }_{17}$ Miki 1963, pp. 16-17. For trading between Tang and Silla, see Kim 1966, pp. 78-9.
} 
c. 760). ${ }^{18}$ Supplementary Commentary on the Materia Medica of the Heavenly Husbandman (嘉祐補註神農本草, 1061, hereafter Supplementary Commentary), which was compiled by Zhang Yuxi (掌禹錫 960-1279), also recognised the relatively high quality of ginseng from the Silla Kingdom in the 'Discourse on the Nature of Medicinal Drugs' (藥性論). Although Supplementary Commentary was compiled long after the Unified Silla Dynasty ended, ginseng from Korea was still referred to as 'Silla'. ${ }^{19}$

'Silla ginseng', identified by its habitat, continued to be mentioned in Song materia medica as evidenced in both Su Song's (蘇頌, 1020-1101) Illustrated Classic of Materia Medica (本草圖經, Song Dynasty) and An Exposition of Materia Medica (本草衍義, Song), compiled by Kou Zongshi (寇宗龭, 12th century). ${ }^{20}$ Sources available now, such as Illustrated Classic of Materia Medica, Materia Medica for Emergency Use, Classified and Verified from the Classics and Histories (經史證類備急本草, c. 1082), and History of Korea (海東歷史, c. 1800) also recognise several kinds of botanicals as 'Silla' ${ }^{21}$ For instance, Silla beef tallow (新羅牛脂) and Silla peppermint (新羅薄荷) were recorded in the Illustrated Classic of Materia Medica and in texts kept in the Shōsoin Treasure Repository (正倉院御物), respectively. ${ }^{22}$ This distinction, made by combining species and a particular habitat, shows how botanicals from Korea gained a name and place within the Chinese classification system. Other than examples such as these, it is difficult to trace how Korean locality was mapped onto botanicals.

Imported materia medica from China were prestige goods during the Silla Dynasty. History of the Three Kingdoms reveals that Silla aristocrats were expected to make a conspicuous display of their status which was measured in a system known as 'bone rank' (kolp'um, 骨品) according to sumptuary regulations. ${ }^{23}$ Found among the gems, fur goods and plants forbidden to the lower

18 Miki 1963, p. 18.

19 Kim 2001, pp. 8-9, 16-17.

20 Miki 1963, p. 18.

${ }^{21}$ History of Korea written by Han Ch'i-yun (韓致婣, 1765-1814) has been viewed by contemporary historians as an exemplary work of Practical Learning (Sirhak, 實學) scholarship, which reveals increased interest in the history and geography of the Eastern Kingdom (東國), Korea. A couple of texts were written with the title of the 'Eastern Kingdom' or 'Eastern region (海東)' during the eighteenth century. Han collected records on Korea from Chinese or other non-Korean sources. Hence, more than 500 Chinese texts and 20 Japanese texts were examined. His work amounts to 70 volumes and was followed by 15 more volumes by his nephew. Only one handwritten copy survives to the present. Lee 1984, pp. 236-8.

${ }^{22}$ Miki 1963, pp. 17-21.

23 Silla had the 'bone rank (kolp'um)' system as a way of structuring the aristocracy along hereditary bloodlines. Six grades of 'head-rank' (頭品) existed in addition to 'hallowed bone' (sŏnggol) and 'true bone' (chingol). Head-ranks six, five and four formed the run-of-the-mill 
ranks of aristocracy were also materia medica: black rhinoceros horn (烏姩), red sandalwood (紫檀), aquilaria agallocha (沈香). Most of these goods were imported from the continental Western Region (西域) for aristocratic use. ${ }^{24}$

In this flow of material goods and books, the latest Chinese texts and some rare materia medica were taken up by Koreans, while ginseng and ox gallstone were often offered to the Tang court as tribute. Chinese texts, as well as some Japanese sources, acknowledged 'Silla' as a geographic classification mapping the diversity of botanicals. Still, the regional variety of botanicals was mentioned in passing by the Chinese sources, without any exclusive emphasis on ethnic distinction. Considering the extreme diversity of botanical names, shapes and attributes, it seems more of an artificial invention than a natural outcome to define what belongs to 'us' and 'them'. In a similar vein, correcting the names of botanicals, committing the folk names of certain species to scholarly texts, and publishing a series of books focusing on local botanicals all reflect a social and cultural need to evoke the 'local' with respect to materia medica. To scrutinise this process, it is necessary to view the Koryŏ Dynasty's (918-1392) medical publications. The medical writings of this dynasty provided the terms for and patterns of local botanicals upon which writers of its successor dynasty, the Choson, articulated and broadened their claims to the unique nature of local botanicals. In doing so, they conjured up their own tradition of Eastern medicine (東醫). The Koryŏ Dynasty's interest in local botanicals and the following Chosŏn Dynasty articulation established two major texts, Prescriptions of Local Botanicals for Emergency Use (鄉藥救急方, c. 1236) and Standard Prescriptions of Local Botanicals (㰾藥集成方, 1433), as the foundation of Korean materia medica.

\section{Texts on Medicine in Circulation during the Koryŏ Dynasty}

Koryŏ literature on local botanicals, even though comparatively better documented than that of Silla, is still insufficient to fully illustrate the entire process of making local botanicals significant. One collection of prescriptions, Prescriptions of Local Botanicals for Emergency Use (㰾藥救急方, c. 1236), survives to the present time. There are also comments on medicine found in History of Koryo (高麗史, 1454) and Essentials of Koryo History (高麗史節要, 1452).

nobility. Only hallowed bone and true bone families were eligible for the throne. For general description of the 'bone rank' system, see Lee 1984, pp. 48-51.

${ }^{24}$ The Western Region includes what is now known as Xinjiang (新疆) and parts of Central Asia. Illustrated Pharmacopoeia describes black horn of rhinoceros and aquilaria agallocha from the Southern Region (南方 or 南國). Textual Traces of Materia also indicates that red sandalwood comes from the Southern Region. Miki 1963, pp. 20-1; Kim 1966, pp. 82-4. 
These sources imply that foreign materia medica were often introduced to the Koryŏ court by merchants and envoys from China, Japan and Arabia. These visitors offered a variety of rare and precious goods, including materia medica. In return, the Song court was offered ginseng, pine nuts and fragrant oil. Elecampane inula (木香), clove (丁香), and aquilaria agallocha (沈香), in addition to rhinoceros horn imported from the Southern Regions, were popularly bestowed on the Koryŏ Dynasty court in return. The list of imperial gifts presented to King Munjong (文宗, r. 1047-1082) by the Song Emperor includes the name and origin of more than 100 Chinese materia medica. Described as 'clove of Guangzhou' (廣州丁香), 'crowdipper of Jizhou' (薺州牛夏), 'rhubarb of Shuzhou' (蜀州大黃), and 'licorice of Yuanzhou' (原州甘草), these materia medica signified imperial benevolence to a neighboring Korean king, who was suffering from paralysis caused by a stroke. ${ }^{25}$

King Munjong also consulted experts on matters of his personal health. According to five sets of records in History of Koryŏ, medical experts from the Song were mostly concerned with treating Munjong's numbness, and it is conjectured that Song physicians brought medical texts and herbs with them. Xin Xiu (壃修), who was naturalised as a Koryŏ subject during King Munjong's reign, was known for his medical knowledge, even though he was not a medical official. Xin's medical specialty was handed down to his son, Xin Anzhi (壃安之). Another Chinese, Xu Jing (徐嘲), accompanied the envoys dispatched to Koryŏ during the reign of Song Emperor Huizong (徽宗, 110025) and wrote of his experience in the Koryo capital in a book entitled Illustrated Classic of Koryo Written by the Envoy of the Xuan Huo Period (宣和奉使 高麗圖經, 1123). Composed of 29 sections (門) and 300 entries (條), this account includes a few comments on the medical customs of Koryŏ, such as the tea ceremony, preservation of ginseng, and domestic trade in medicine. ${ }^{26}$

Paralleling the flow of medical experts and materia medica was an increase in the diffusion and circulation of texts. Three types of sources provide evidence about the transmission and publication of texts. The first are Chinese medical texts compiled by the Koryo Dynasty. Song medical texts such as Imperial Grace Formulary (太平聖惠方, 982) and The Divine Physicians' Prescriptions for Universal Deliverance (神醫補球方, 986) seem to have been imported by official envoys in 1016 and 1022, respectively. It was during King Munjong's reign that this kind of intermittent textual importation was replaced by orderly, planned state publication. Sources reveal that medical texts were published in Korea in 1056, 1058 and 1059, including classics such as The

\footnotetext{
25 Miki 1963, pp. 47-8; Kim 2001, pp. 39-40.
}

${ }^{26}$ Miki 1963, pp. 55-8; Kim 1966, pp. 119-24. 
Yellow Emperor's Canon of 81 Problems (黃帝八十一難經, c. 2nd century) and The Treatise on Cold-Damage Disorders (傷寒論, 196-220). ${ }^{27}$ This does not mean that those classics were first introduced to Koryŏ during these years, but rather reflects the increasing demand for these texts. Certainly, Chinese medical literature was regarded as more than just an emblem of diplomatic recognition. In addition, official Korean publication of medical texts reflects the level of cultural pride and in-depth knowledge of the classics of Chinese medicine during the Koryŏ Dynasty. The Song emperors were aware of this collection and publication of Chinese medical texts: emperor Zhezong (哲宗 10851100) ordered his envoy to Koryŏ to look for fine woodblock copies of 11 medical texts. ${ }^{28}$ Although only one text, The Yellow Emperor's Classic of Acupuncture (黃帝銊經), was actually sent to the Song rulers from the Koryŏ court, this list identifies possible texts that the Koryŏ dynasty might have added to the court's collection. The last record that enables us to speculate about the extent of Chinese medical texts circulating in Koryŏ has been provided by Chosŏn scholars' examination of an archive where most of the texts that were imported or engraved during the Koryŏ Dynasty have been preserved. ${ }^{29}$

Within these lists of Koryŏ publications are a few texts that have actually been classified by modern historians of Korean medicine as native to Koryŏ. These references are either to texts that were written by Koryŏ experts or to texts on the subject of 'local botanicals'. A finer issue here is to see what attempt, if any, was made at distinguishing the native works of Koryŏ from the texts that were flowing into Koryŏ from the Song Dynasty. What kind of content and authorship defined a medical text as indigenous? What socio-economic and cultural factors promoted the need to classify some botanicals as 'folk' or 'local'? Tables 1 and 2 summarise bibliographical information on major Koryŏ publications that was assumed to have been written by Korean authors or that included references to local botanicals.

27 Kim 2001, p. 46.

28 For more details, see Miki 1963, pp. 45-6, 49.

${ }^{29}$ Kim 2001, pp. 44-6. 
Table 1: Major texts assumed to be written by Korean experts of the Koryŏ Dynasty ${ }^{30}$

\begin{tabular}{|c|c|c|c|}
\hline Title & Date & Author & Availability \\
\hline $\begin{array}{c}\text { Effective Prescriptions for } \\
\text { Universal Salvation } \\
\quad \text { (濟衆立效方) }\end{array}$ & c. 1167 & $\begin{array}{l}\text { Kim Yŏng-sŏk } \\
\text { (金永錫) }\end{array}$ & $\begin{array}{l}\text { Lost, } 1 \text { formula found in } \\
\text { Standard Prescriptions of } \\
\text { Local Botanicals } \\
\text { (鄉藥集成方). }\end{array}$ \\
\hline $\begin{array}{c}\text { New Collection of Essential } \\
\text { Prescriptions of Court Physicians } \\
\text { (新集御醫撮要方) }\end{array}$ & c. 1226 & $\begin{array}{l}\text { Ch'oe Chong-jun } \\
\text { (崔宗峻) }\end{array}$ & $\begin{array}{l}\text { Lost, dozens of formulae } \\
\text { found in Standard Prescrip- } \\
\text { tions of Local Botanicals. }\end{array}$ \\
\hline $\begin{array}{c}\text { Efficacious Prescriptions for } \\
\text { People of the East } \\
\text { (東人經驗方) }\end{array}$ & $?$ & Unknown & Lost, only title is known. \\
\hline $\begin{array}{c}\text { Illustrated Instructions on } \\
\text { Pulse Diagnosis } \\
\text { (診脈圖訣) }\end{array}$ & 1389 & $\begin{array}{l}\text { Chŏng To-jŏn } \\
\text { (鄭道傳) }\end{array}$ & $\begin{array}{l}\text { Written during the early } \\
\text { Chosón. }\end{array}$ \\
\hline
\end{tabular}

Table 2: Major texts labelled as about local botanicals during the Koryŏ Dynasty ${ }^{31}$

\begin{tabular}{|c|c|c|c|}
\hline Title & Date & Author & Availability \\
\hline $\begin{array}{l}\text { Prescriptions of Local Botanicals } \\
\text { for Emergency Use } \\
\text { (㟴藥救急方) }\end{array}$ & c. 1236 & Unknown & One edition is preserved in Japan. \\
\hline $\begin{array}{c}\text { San Hezis Prescriptions Using } \\
\text { Local Botanicals } \\
\text { (三和子挀藥方) }\end{array}$ & ? & Unknown & $\begin{array}{l}\text { Lost, title was mentioned } \\
\text { in the preface of Standard } \\
\text { Prescriptions Using Local Botanicals } \\
\text { for Universal Salvation } \\
\text { (鄉藥濟生集成方). }\end{array}$ \\
\hline $\begin{array}{l}\text { Old Prescriptions Based on } \\
\text { Local Botanicals } \\
\text { (㟴藥古方) }\end{array}$ & ? & Unknown & $\begin{array}{c}\text { Lost, title and } 4 \text { formulae found in } \\
\text { Standard Prescriptions of Local } \\
\text { Botanicals. }\end{array}$ \\
\hline $\begin{array}{c}\text { Tested Prescriptions Using Local } \\
\text { Botanicals to Benefit the People } \\
\text { (挀藥惠民經驗方) }\end{array}$ & ? & Unknown & $\begin{array}{c}\text { The title and } 26 \text { formulae found in } \\
\text { Standard Prescriptions of Local } \\
\text { Botanicals. }\end{array}$ \\
\hline $\begin{array}{c}\text { Easy Prescriptions Using } \\
\text { Local Botanicals } \\
\text { (鄉藥簡易方) }\end{array}$ & $?$ & Unknown & $\begin{array}{c}\text { The title and } 50 \text { formulae found in } \\
\text { Standard Prescriptions of Local } \\
\text { Botanicals. }\end{array}$ \\
\hline
\end{tabular}

30 This table is drawn from the descriptions in Miki 1963, pp. 54-5, 60-2; Kim 2001, pp. 50-1; Kim 1966, pp. 136-7.

31 This table is drawn from the descriptions in Miki 1963, pp. 67-9; Kim 2001, pp. 52-6; Kim 1966, pp. 139-40. 
Historians of medicine in Korea today see these texts as local publications, not reprints of Chinese works. Such texts have been interpreted as signs of the independence or the localisation of Koryǒ's own medicine. However, although these texts were written by Korean authors, the content appears to be based on Song and Tang literature. As Miki Sakae has pointed out, sections of Effective Prescriptions for Universal Salvation (濟衆立效方) reflect direct influence from Chinese texts circulating in Korea during the previous Silla and Unified Silla Dynasties. Kim Tu-jong has compared the prescriptions presented in Effective Prescriptions for Universal Salvation and New Collection of Essential Prescriptions of Court Physicians (新集御醫撮要方) with those of Essential Secrets of the Palace (外臺秘要, 752), Essential Prescriptions Worth a Thousand, for Emergency Use (備急千金要方, c. 650-9), and significant medical classics of Tang China. He hints at only minor modifications in dosage, therapeutic methods and herbal entities, while accounts of symptoms and the courses of diseases follow the Chinese originals. Based on these modified prescriptions and the fact that they were actually included in the Chosŏn Dynasty's grand compilation of Standard Prescriptions of Local Botanicals (墽藥集成方, 1433), he concludes that there was a turn toward independent and indigenous medicine. ${ }^{32}$

\section{Layers of the 'Local'}

In tandem with texts written by Korean authors, texts including the phrase 'local botanicals' in their titles should be examined. Particularly, Prescriptions of Local Botanicals for Emergency Use (墽藥救急方, c. 1236) enables us to look at what was actually classified as and named 'local'. This text is one of the oldest known on local botanicals in Korea. Furthermore, this text is known to have provided the basic structure and content for the authors of the later Standard Prescriptions of Local Botanicals (墽藥集成方, 1433), which is one of the most significant medical texts of the early Chosonn Dynasty. Continuities in style and content between these two texts have often been highlighted by modern historians of Korean medicine. ${ }^{33}$

Two issues have to be underlined regarding the structure and content of Prescriptions of Local Botanicals for Emergency Use. This work employs the organisational system of Tao Hongjing's (陶弘景, 456-536) Collected Commentaries on Classical Materia Medica of the Heavenly Husbandman (本草經集註, c. 530-57), which sets up three layers of drug quality, to arrange the materia medica. Prescriptions of Local Botanicals for Emergency Use is composed of three

32 Miki 1963, p. 55; Kim 1966, pp. 136-41.

33 Miki 1963, pp. 62, 127; Kim 2001, p. 345; Kim 1966, pp. 139-41, 195-6. 
volumes, and each volume is classified according to the upper (上), middle (中), and lower (下) divisions. ${ }^{34}$ Alongside these sections, a list of local botanicals, 'Pangchunghyangyakmokch'obu' (方中鄉藥目草部, hereafter List of Local Botanicals) presented 180 species. ${ }^{35}$ Here the local name, attributes, toxicity, and the method of collecting each herb are described. Although the herbs introduced here are identified as 'local' to Korea, most information on them was taken from Chinese texts of materia medica.

Not all of the 180 species introduced in the List of Local Botanicals are plants uniquely native to Korea. For instance, iris (菖蒲), liriope platyphylla (麥門冬), euphorbia pekinensis (大戟), and ox gallstone (牛黃) were already well-known in the texts of Chinese materia medica. Most species were grown in Korea, but they were not exclusive to Korea. They are classified as 'local' because they were grown in Korean soil. More to the point, the species categorised as 'local botanicals' were identified with a folk name (俗云), written in Chinese characters, yet pronounced differently from the Chinese. Known as the 'idu' (吏讀) system, this method employs Chinese characters to signify Korean pronunciation arranged in a Korean word order. ${ }^{36}$ “松衣羅” is thus the idu folk name for a species like the iris (菖蒲), '冬沙伊' is idu for liriope platyphylla (麥門冬), '數板麻' is idu for astragolus membranaceus (黃者), and “狄小豆” is idu for cassia tora (決明子). ${ }^{37}$ However, not all species were designated by folk names. Some already well-established herb names, such as the names of ginseng, ox gallstone, rehmannia glutinosa (地黃), and chrysanthemum (菊花), were based on the Chinese names. In addition to the local botanicals recorded in List of Local Botanicals, more than 40 botanicals that are not registered in List of Local Botanicals, such as rhinoceros horn, licorice and ginger, are found in the prescriptions of Prescriptions of Local Botanicals for Emergency Use to which the List of Local Botanicals belongs. ${ }^{38}$ Among them are included botanicals that were easily found in Korean soil, such as ginger and mustard.

${ }^{34}$ Prescriptions of Local Botanicals for Emergency Use (鄉藥救急方), pp. 3-5. Since this text was intended as an emergency aid, each division contains a brief introduction to relevant symptoms, such as 'food poisoning' (食毒) in the first volume (上卷) or the 'miscellaneous disease of females' (婦人雜病), 'the contrary attributes of medicinal drugs' (藥性相反), and 'the written formulae of experience passed from the past' (古傳錄驗方) in the third volume (下卷). For more details, see Kim 2001, pp. 57-9.

35 For List of Local Botanicals, see Prescriptions of Local Botanicals for Emergency Use, pp. 91-102.

36 Regarding 'idu' (吏讀), see Lee 1984, p. 57.

37 It is unknown how to read the $i d u$ pronunciation. Hence, I put only Chinese characters as they were shown in the List of Local Botanicals.

38 Regarding these 40 herbs, see Kim 2001, pp. 66-7. 
To summarise, the List of Local Botanicals incorporated in Prescriptions of Local Botanicals for Emergency Use included some 'local' botanicals that were not native to Korean soil. Some botanicals that were excluded from the list, but included in the prescriptions, were found in the local habitat. What, then, was the primary standard used to classify these species as 'local' herbs? The boundaries of this category remained ambiguous. As its title suggests, Prescriptions of Local Botanicals for Emergency Use was compiled for the convenience of those people who had difficulties reaching good doctors and proper prescriptions. Using botanicals locally available, Prescriptions of Local Botanicals for Emergency Use aimed to provide a practical tool for physicians or householders managing health and disease. Given this milieu, the intrinsic inconsistency in the way botanicals were considered and treated as local might not have been the main concern of the text's editors. Even so, the way local botanicals were committed to scholarly text should be scrutinised, because Prescriptions of Local Botanicals for Emergency Use has been viewed as a significant step toward the 'independent development of our own medicine', and the 'self-management of medical policy'. ${ }^{39}$ Furthermore, Miki Sakae suggests that the continuous tradition of local botanicals that began with this book resulted in the establishment of Korea's own study of materia medica, during the following Chosŏn Dynasty, thereby contributing to the growth of indigenous medicine. ${ }^{40}$ Hence, the identification of botanicals as local should be analysed in the light of its significance in portraying Korea's own tradition of medicine.

As was discussed earlier, the 'local' documented in Prescriptions of Local Botanicals for Emergency Use implies an indigenous nomenclature, yet the folk names themselves were not standardised. Some folk names, presented in idu in both the prescriptions of Prescriptions of Local Botanicals for Emergency Use and the List of Local Botanicals, did not match. For instance, angelica (當歸) was rendered as 黨歸荣根 $i d u$ in the prescriptions of Prescriptions of Local Botanicals for Emergency Use, whereas angelica was described as 且貴草 $i d u$ in the List of Local Botanicals. Angelica polymorpha (窮芦) was presented as 芦芦草 $i d u$ in the prescriptions while listed as 蛇休草 $i d u$ in the list. And if that is not confusing enough, whereas the 'folk name' (俗云) is displayed in the list, the 'local name' (墽名) was used in the prescriptions.

Explaining this discrepancy, scholars have pointed out that even though both the List of Local Botanicals and the prescriptions were included in Prescriptions of Local Botanicals for Emergency Use, these works were compiled at two different times. While the prescriptions utilised 'local names' as a way to

\footnotetext{
39 Kim 1966, p. 141.
}

${ }^{40}$ Miki 1963, p. 127. 
put Korean herb names in an official publication, the items on the List of Local Botanicals employed folk names known to ordinary people. These two different nomenclatures_-folk names for the list and local names for the prescriptions - seem plausible, because when another list of local botanicals, in Standard Prescriptions of Local Botanicals, was compiled during the early Chosŏn period, the list mainly relied on names listed in the prescriptions, thus continuing to adopt the 'local name' as a means of emphasising local identity but never incorporating the 'folk names' from the List of Local Botanicals. ${ }^{41}$

The incongruity revealed in the naming of local botanicals illustrates the complexities involved in defining local botanicals. Most well-known materia medica, such as ginseng and ox gallstone, did not need a local name. When 180 species were categorised as 'local botanicals', the implication was that the botanicals were locally available but not necessarily locally grown. Some botanicals included in the prescriptions were apparently supplied by foreign trade. ${ }^{42}$ Even herbs that were seemingly popular and generally adapted to Korean soil had a variety of names according to the habitat and production. Finally, it should be noted that when these local botanicals were committed to scholarly text, the scholarly apparatus still referenced major Chinese texts of materia medica. As recent research by the Korea Institute of Oriental Medicine has shown, the List of Local Botanicals in Prescriptions of Local Botanicals for Emergency Use relied on Collected Commentaries for information on the morphologies and seasons of herbs, and on Illustrated Classic of Materia Medica (本草圖經, Song Dynasty) for their general attributes, toxicities and medicinal effects. Thus, it is plausible to surmise that Prescriptions of Local Botanicals for Emergency Use was compiled in line with Materia Medica for Emergency Use, Classified and Verified from the Classics and Histories (經史證類備急本草 c. 1082), which synthesised Collected Commentaries and Illustrated Classic of Materia Medica, while adding the folk names of some of the available local botanicals. $^{43}$

Certainly, Koryŏ's compilation of 'local botanicals' has historical significance, since Prescriptions of Local Botanicals for Emergency Use is viewed as the oldest medical text of 'our own', and is distinguished from other replicas of Chinese texts published in the earlier period. Five other published medical texts on 'local botanicals' are known only from quotations excerpted in later

41 Kim 2001, pp. 67-8.

42 See my discussion about licorice (甘草) in the following pages. The Korean attempt to naturalise licorice was not successful. Now more than 90 per cent of the licorice root consumed by Koreans comes from China.

43 Kim 2001, p. 67. 
publications. ${ }^{44}$ These texts have also been regarded as evidence of a turn toward independence and localism in Korean medicine. However, as was shown in the previous section, the 'local' was recognised and presented as textual knowledge without any clear-cut classificatory scheme of local botanicals. Through the foregoing discussion we can identify that the authors of these materia medica were using three different definitions of what 'local' means when referring to the identity of botanicals: first, botanicals available to Koreans but mostly imported; second, botanicals grown locally but also found in other places; and third, botanicals with local or folk names. These three perceptions of 'local' identity often overlapped in practice and were hardly organised into a clear set of contemporary catalogues, even though the term 'local botanicals' has been frequently celebrated by historians of Korean medicine. To see how boundaries such as 'local botanicals' and 'Chinese botanicals' (唐藥) were drawn around the diverse and uncountable varieties of herbs necessitates the consideration of additional ideological and cultural stimulants that were catalyzed by the new political regime of the Chosonn Dynasty.

\section{The Rise and Fall of Local Botanicals}

\section{Materia Medica in the Early Chosŏn Dynasty (朝鮮, 1392-1910)}

During the early Chosŏn period, medical experts, medical literature and materia medica were all in vigorous circulation. Many records in Veritable Records of the Choson Dynasty (朝鮮王朝實錄, hereafter Veritable Records) indicate that tributary envoys to Ming China became a major route for the herb trade. As in Koryŏ, dozens of medicines, such as ginseng, pine nuts and deer horn, were often offered by the Chosŏn court to the Ming court, whereas ox gallstone, borneol, cinnabar, pepper, in addition to frankincense (乳香) were listed as materials sent from the Ming court to Chosǒn. ${ }^{45}$ Mostly, tribute offerings ranged in the hundreds of kŭn (斤) per item. ${ }^{46}$ Since Chinese materia medica were highly appreciated and in vital demand, Chosǒn rulers ordered medical officials to accompany tributary envoys and manage the overall herb trade. In

\footnotetext{
${ }^{44}$ They include San Hezi’s Prescriptions Using Local Botanicals (三和子墽藥方), Old Prescriptions Based Local Botanicals (鄉藥古方), Efficacious Prescriptions for People of the East (東人經驗方), Tested Prescriptions Using Local Botanicals to Benefit the People (鄉藥惠民經驗方), and Easy Prescriptions Using Local Botanicals (鄉藥簡易方). See Miki 1963, pp. 67-8.

${ }_{45}$ Kim 2001, p. 240.

${ }^{46}$ One kŭn (斤) is now approximately $600 \mathrm{~g}$ for measuring medicinal herbs. Regarding SinoKorean tributary relations and items of tributary offering, see Clark in Twitchett and Mote (eds) 1998, pp. 290-3.
} 
addition, the medical officials who attended to the tributary envoys were expected to have enough knowledge and experience to verify the quality of the Chinese materia medica. Although the exact scale of trade is not known, private trade could not be rigidly controlled by state regulation. Memorandums to the throne often urged state intervention to correct 'evil practices' in the herb trade, and disclosed various problems that arose as a result of the ambiguous borders between official and non-official trade. ${ }^{47}$

Herb trading was also carried out with other kingdoms. Veritable Records comments on the herb trade with Japan (日本國) and the Ryuku Islands (琉球國) from the late fourteenth century to the middle of the fifteenth century. South Asia was intermittently mentioned, whenever its merchants came to trade. Trade was an official diplomatic practice authorised and regulated by the offices of the Chosŏn Dynasty. Materia medica brought by Japanese merchants was primarily intended to meet royal demand with surplus authorised for use in private trade. Japanese merchants, however, preferred private to official trade, and thus they often hid some precious materials from royal eyes. ${ }^{48}$

Some of the more obvious features of this circulation become evident when we examine the medical experts who crossed dynastic boundaries during the late fourteenth through sixteenth centuries. Veritable Records describes a Japanese monk who was naturalised along with his family and ascended to a high official rank under the reign of King T'aejong (1400-18). Chosón envoys often asked the Ming emperor to send medical experts, while many medical officials who accompanied Korean official envoys tried to acquire more literature, materia medica and knowledge from Ming physicians. Some texts actually enable us to reconstruct this dialogue between Ming scholars and Chosŏn medical officials. Sino-Korean Questions about Prescriptions (中朝質問方), SinoKorean Prescription Transmission and Practice (中朝傳習方), Questions on Medicine (醫學疑問), and Answers to the Questions of a Korean Physician (答朝鮮醫問) are known to present-day scholars, although not all have survived. The fact that there is a Japanese edition of Answers to the Questions of a Korean Physician tells us the range of this text's circulation during the eighteenth century. ${ }^{49}$

\footnotetext{
${ }^{47}$ A report to King Sejong in 1432 reveals that the Chosŏn Dynasty was seeking efficient means to control trading items, such as musical instruments, texts and materia medica. It is said, 'Although private trade with Ming was prohibited, it seems impossible to prevent dealings in musical instruments, texts, and materia medica.' The king ordered a report of a possible way to regulate the trade. In 1433, an envoy to Ming was ordered to purchase various Chinese botanicals (唐材) by observing the decorum of Ming China. Kim 2001, pp. 229-30, 234-5; Kim 1966, pp. 203-4.

${ }^{48}$ Kim 2001, pp. 241, 256-60; Kim 1966, pp. 204-5.

${ }_{49} \mathrm{Kim}$ 1966, p. 263; Liang 2001. Liang analysed medical exchanges between China and Korea presented in Essentials of Medical Works, which was compiled by Korean court physicians,
} 
A finer issue here is provided by analysing Answers to the Questions of a Korean Physician, a text in dialogic form which transcribed the answers of Wang Yinglin (王應隣), a Chinese official in the Ming Dynasty, to the questions of Yun Chi-mi (尹知微), a Korean official physician. Composed of 24 articles and written in classical Chinese, this conversation reveals issues significant for Korean physicians. The discussion reveals the shared theoretical framework through which Koreans understood medical problems, and it informs us about the textual sources through which medical knowledge was articulated and supplemented. As has been shown by Liang Yongxian, the issues addressed ranged from understanding unresolved clinical symptoms to elaborating details of the body's circulation channels and arriving at specific therapies for diseases. ${ }^{50}$ Although this text was transcribed in the early seventeenth century and was copied during a later period in both China and Japan, the text exemplifies the way in which the encounters of medical specialists across dynastic borders became a method of furthering medical knowledge. The experts' encounters did not merely remain in the realm of diplomatic formality, but generated paths through which the latest interpretations of diseases, novel prescriptions, and empirical therapies were transmitted via interpersonal communication.

Paralleling this flow of material trade and interpersonal encounter was an upturn in the appeal to 'local botanicals' or 'locality' as an authority in textual forms of knowledge. This upturn was consonant with a more enhanced claim for a medicine that was more appropriate to the native soil. In the following sections, I will first examine the role of the state in compiling and developing knowledge of local botanicals. Second, texts on local botanicals will be analysed in the light of their themes, rhetoric and impact on later medical publications.

\section{The Chosŏn Dynasty's Identification of Local Botanicals}

As medical texts circulated more widely, the Chosŏn Dynasty decided it was significant to distinguish locally grown botanicals from foreign botanicals. This was done by identifying the names, shapes and attributes of local botani-

Chŏng Chŏng-sŏn (鄭正先) and Yang Ye-su (楊禮壽), during the late sixteenth and early seventeenth centuries. The last edition was completed with 13 volumes and 128 categories, reflecting the latest medical literature from Ming China to Chosŏn Korea. From the list of medical literature notated by the authors of Essentials of Medical Works, the other two texts, Sino-Korean Questions about Prescriptions and Sino-Korean Prescription Transmission and Practice are traceable. Essentials of Medical Works also enlisted many Chinese medical experts.

${ }^{50}$ Liang 2000. 
cals and comparing them with Chinese botanicals. Articulating those characteristics was crucial, since some botanicals of the same species had different names and different species were sometimes called by the same name. All of these circumstances complicated the elaboration of the categories of local botanicals and their medical effects. Confusion in identifying botanicals was a significant issue in medical prescription and treatment.

During King Sejong's reign (1418-50), medical officials were dispatched to China to resolve this problem. In 1423, for instance, envoys to Ming China examined 62 Korean species in collaboration with Chinese scholars and found that 14 were different from Chinese species. The goal was to discover what kind of local product could be used as a substitute for Chinese materia medica. Dozens of botanicals, such as machilus thunbergii (厚朴) turned out to be different from Chinese products, and were forbidden for use in medical preparation. Additionally, in 1430 and 1431, the officials of King Sejong attempted to discriminate between the qualities of domestic botanicals, hoping to substitute them for the Chinese botanicals that were named in prescriptions. ${ }^{51}$

In conjunction with this identification and comparison, the dynasty continued to localise foreign botanicals, particularly those in high demand. A few remarks in Veritable Records reveal an attempt to grow licorice (甘草) during the Chosŏn period. For instance, King Sŏngjong (成宗, r. 1469-94) encouraged the localisation of licorice, which became more than just a transitory project. The Miscellaneous Ordinance of the Code of Rites (禮典雜令) informs us that during the early Chosŏn Dynasty, the local cultivation of licorice was directed by officials dispatched from the Royal Hospital (內醫院). The officials were expected to check the cultivation conditions in every province at least once a year. Not only licorice but also pepper (胡椒), ephedra sinica (or Chinese ephedra 麻黃), and alpinia galanga (良畺) were plants that Koreans tried to naturalise in Korean soil, according to Veritable Records. ${ }^{52}$

The state also made more systematic efforts to compile a record of local botanicals. The Geographical Gazette of the Eight Provinces (八道地理誌) was first compiled in 1432 and then was eventually incorporated into the Veritable Records of King Sejong (世宗實綠). ${ }^{53}$ Commissioned to record the administrative history of each local government jurisdiction, its topographical features, control checkpoints, fortifications, land area, population, native products, roads and post stations, garrisons, troop levies, beacon communication sites, mausolea and tombs, surnames found in the area, and historical personages, the Geographical Gazette of the Eight Provinces reflects and summarises the

\footnotetext{
${ }^{51}$ Miki 1963, pp. 125-6; Kim 2001, pp. 345-7; Kim 1966, pp. 206-8.

${ }^{2}$ Kim 2001, pp. 370-4.

${ }^{53}$ Lee 1984, p. 194.
} 
information deemed necessary by the dynasty to govern local provinces. Under the category of native products, a section called 'materia medica in production' (生産藥材) listed all botanicals growing in a certain province. Although some were given local names, most used the names found in Chinese medical texts. Cumulatively, the eight provinces were said to produce 1,080 separate plants, and they were categorised into approximately 317 species. In the category of 'materia medica in cultivation' (種養藥材), dozens of botanicals under cultivation were delineated according to the administrative units. Finally, the category of 'materia medica for offering to the king' (進上藥材) was added to specify the items and quantities of materia medica that should be sent to the capital. Fulfilling this quota was the responsibility of local magistrates. ${ }^{54}$

The court's initiative in managing materia medica was further enhanced with the category of 'materia medica for offering to the king'. Beginning during King Sejong's reign (1418-50), an 'offering to the king' was distinguished from a general tribute (貢物) in the legal code. An official announcement by the Ministry of Finance (戶曺) in 1432 ordered that among the general tributes offered by each province, materia medica should be separately managed and reserved for one of three major medical offices: The Palace Clinic (內醫院), the Directorate of Medicine (典醫監), or the Office of Benefiting the People (惠民署). In 1434, regulations were inaugurated to administer the process of collecting, transporting and managing materia medica for royal use. If there were enough stored herbs to meet annual supply needs, the rest was distributed for general use. As herb trade increased during the fifteenth and sixteenth centuries, evidence of malpractice as well as illegitimate smuggling was often found in Veritable Records. ${ }^{55}$

The 'materia medica for offering to the king', the dynasty's attempt to amass botanicals from local districts, is also related to two more issues in the history of Korean medicine. The first is the impact of this practice during the early Chosŏn Dynasty on the development of an herbal drug market (藥令市) after the late seventeenth century. ${ }^{56}$ As revealed by modern scholarship, the begin-

54 Kwŏn 1986, p. 53; Kim 2001, pp. 347-64.

55 Kwŏn 1986, pp. 55-6.

56 Scholars have examined the origin and scope of herbal drug markets, which were held in a few commercial centres in Chosŏn. Among them, Taegu (大邱), a southeastern centre of administration, was well-known for its herbal drug market, where herb items flowed in from South Asia and Europe, not to mention China and Japan. As a distinct kind of inter-regional and international commercial activity, the herbal drug market gained scholarly attention beginning in the early twentieth century. Indeed, the scholarly focus began with Japanese scholarship carried on during the colonial period (1910-49) and was revised by Korean scholarship after 1945. Both studies ascribe the rise of this herbal drug market to the tributary offering and the (non)official trade with Ming/Qing China, the overall increase of domestic market, and the 
ning of the herbal drug market in the seventeenth century highlights the role the state played in the form of the 'materia medica for offering to the king' in allocating botanicals between provinces, circulating botanicals across borders and regional boundaries, and diffusing knowledge of local botanicals. Taegu (大邱), for instance, a central locus of the Kyŏngsang province located in southeastern Korea, became a more significant place because of its collection of the 'materia medica for offerings to the king'. During the seventeenth century, Taegu supplied more than 50 per cent of the plant varieties being offered to the king, and more than 16 per cent of the total volume of tributary herbs. More than 30 per cent of the medical agents employed by local officials were headquartered there. In the eighteenth and nineteenth centuries, Taegu grew into a major private herb market centre with more than 100 permanent herb shops and thousands of agents engaged in this trade. The gradual shift from state regulation to the private management of medicine has thus gained scholarly attention, ${ }^{57}$ yet it has not been demonstrated whether this expansion of the private market into local districts paralleled a development of a regional identity for medicine within Korea.

Second, the state's involvement in the promotion of local botanicals leads us to ask whether these local botanicals, either as material entities or as forms of knowledge, had any impact on the lives of ordinary people. Regarding this issue, recent scholarship has presented conflicting ideas on whether the state's project of encouraging the production and use of local botanicals resulted in real medical effects, such as a reduction in infant mortality or the promotion of population growth. This issue is beyond the scope of this paper, yet it should be remembered that narratives concerning local botanicals did not always represent actual medicinal effects. ${ }^{58}$ With this in mind, the following section

extended practice of 'Uniform Land Tax Law'. (大同法) This law promulgated rice, instead of other local specialties, as a means of paying taxes and was carried out first in Kyŏnggi (京畿) and Ch'ungch'ong (忠青) provinces, and then in Kyŏngsang province during the seventeenth century. As the character '令' of the herb drug market (藥令市) indicates, this market was held annually with a state proclamation primarily to meet the dynasty's demand. However, as this market concomitantly attracted commercial interests across regional and political boundaries, private trade gradually grew, and then prospered during the nineteenth century. This herbal drug market continued to flourish until the Japanese occupation in 1910. The new political regime changed the flow of material goods, management patterns, and major merchant connections. Thus, after the colonial period, Seoul, instead of Taegu, emerged as a major locus of the herb trade while Taegu was confined to a few market streets that specialised in traditional medicine. For details, see Kwŏn 1986.

57 Kim Daewon 1998.

${ }^{58}$ Regarding this issue, Yi T'ae-jin argues that the Chosŏn Dynasty encouraged the use of local botanicals as a way of improving medical care and highlighting the ideal of Confucian governing. Analysing 260 epitaphs from the late Koryo dynasty, he argues for a gradual increase 
analyses the rationale for the Chosonn Dynasty's policies, as they have been expressed in texts. Ultimately, the Chosŏn state's method of deploying local botanicals reveals the inevitably ambiguous position of educated people who were situated at the cultural and political margins. They gave priority to the influx of materials, ideas and experts from China. While respecting Chinese knowledge for being the most advanced, physicians of the Chosonn Dynasty still had to adapt it to the necessities of the local situation. This adaptation brings us to individual agency as it was expressed in the relocation of Chinese medicine across geo-political boundaries.

\section{Local Botanicals as a Manifestation of Identity}

Standard Prescriptions of Local Botanicals (䧖藥集成方, 1433) represents a high point in the history of Korean medicine. Historians have already discussed how the official compilation of this title, together with another well-known medical text, Classified Compilation of Medical Prescriptions (醫方類聚, 1477), make a vivid display of the cultural authority and confidence of the newlyfounded Chosŏn Dynasty (1392-1910). Both books were compiled during King Sejong's reign (1418-50), at the same time as the implementation of one of the most sophisticated cultural projects in the entire Chosŏn Dynasty. Extensive collection and modification of information was not confined to the field of medicine but is evident across a range of other fields, including astronomy, agriculture and technology. ${ }^{59}$

of population. This modest growth was continued in the early Chosonn, and maintained with a more effective state policy carried on both in medicine and agriculture. Considering the state publication on local botanicals, and flow of medical literature from Song, Yuan, and Ming China, Yi believes that local botanicals played a more significant role than agricultural innovation in improving infant mortality, thus, ultimately leading the actual growth of population. But Shin Dong-won discounts the role of medicine in population growth, following Thomas McKeown's argument on the relationship between population growth and role of Western medicine. Taking factors such as overall progress in nutrition and an improved immune system, McKeown limits the role of Western medicine in influencing population growth. In a similar vein, Shin thinks that Yi has not fully demonstrated the actual connection between local botanicals and their clinical impact on certain diseases that were supposedly fatal to infants. In addition, Shin observes that the phrase 'died young (早死)' can hardly be equal to 'infant mortality'. See Yi 2003a. Regarding the debate between Yi and Shin, see Shin 2002; Yi $2003 b$.

59 See Mun 2006. Classified Compilation of Medical Prescriptions was first intended to pull together every known piece of medical literature, and then to put them into 91 nosological categories (大綱門). After each discussion, prescriptions from various medical texts were listed chronologically. Detailed annotations and corrections were added, which implies that in-depth knowledge of those medical texts was indispensable for this sort of grand compilation. More than 150 texts from the Han, Tang, Song, and Yuan Dynasties were referenced. The complete Classified Compilation of Medical Prescriptions amounts to 365 volumes. 
The bibliography of Standard Prescriptions of Local Botanicals lists 160 medical texts, mostly transmitted from China. Comprising 57 nosological categories (大綱門) and 959 subsections (門), Standard Prescriptions of Local Botanicals reveals a certain departure from its predecessors. Based on the major classics of Chinese medicine, Standard Prescriptions of Local Botanicals nevertheless stimulated knowledge of local botanicals by also incorporating most of the Koryŏ Dynasty's own texts on local botanicals, providing a list of previously discovered local botanicals, and suggesting some prescriptions with local botanicals. The 959 nosological categories in the new compilation were a substantial increase on the 338 listed before (these had been called 舊證). In addition, the previously known 2,803 formulae were expanded to 10,706, with 1,416 items about acupuncture newly added, and more than 700 species were listed under the category of 'Local Bencao' (㰾藥本草). ${ }^{60}$

There is no doubt that these two medical texts, the most grandiose of the Chosŏn Dynasty, were intended to reflect its cultural confidence and sovereign pride. They elaborated upon why 'we' should value 'our' own publications. The following translation of the preface of Standard Prescriptions of Local Botanicals offers a rationale for the study of local botanicals that was repeated in many later medical publications. The author focused on the interaction of geographic areas, environments, and constitutions.

Since Shennong and Huangdi, later generations have had officials of medicine, and let them manage every person's disease. Every physician is different in diagnosing disease and prescribing medicinal drugs. In general, they exert their skill in line with $q i$. It is unnecessary for all to follow one method (法). In general, the method is different along the distance of $100 \mathrm{li}$ (里), and customs are different along the distance of 1,000 li. The growth of wind, grass, and trees has its own appropriateness. The ways people eat, drink, enjoy, and desire also get accomplished in their own ways. Thus, the sages in the past tasted numerous herbs and followed the characteristics of every region, as the method of healing.

Particularly, for our kingdom (國), heaven allots one region (區) and allows us to inhabit the great East. Precious stuffs are hidden in the mountains and oceans, and the production of grass, trees and medicinal stuffs is possibly enough to support people's livelihoods. Consequently, those who treat people's diseases were also generally well prepared. However, since bygone days, medicine has atrophied, and herbs are not collected in time. People ignore what is close [local] to them; instead, they seek what is far from them. Whenever people contract illness, they pursue Chinese medicinal drugs that are very difficult to get. Why does this happen? Isn't it just like pursuing a three-year-old wormwood for the treatment of disease that has been prolonged for seven years? As a result, medicinal drugs are unavailable, and the disease becomes serious to the extent that it cannot be correctly treated.

${ }^{60}$ Kim 2001, pp. 523-32. 
Rather, a countryman properly treats one disease by [adopting] a single herbal material. The effect of his treatment is quite superb. This kind of efficiency is achieved, since he has treated the disease with medicinal drugs that fit the attributes of the soil. If it is quite understandable that one would go as far as 1,000 li (里) to obtain every possible treatment [for one's disease], then what would it be if it were possible to treat one's disease without going that far, namely just by remaining in the kingdom? People fear [disease] because they do not have any knowledge of it.

In former times, official Kwŏn Chung-hwa (權仲和) tasted and collected various simple formulae of local botanicals. After that, he, with official Cho Chun (趙浚) etc., ordered the official pharmacy to more fully investigate numerous formulae and collect what Eastern people (東人) have experienced, and then differentiate the categories and compile volumes to publish. From then on, medicinal drugs became easy to obtain, and disease became easy to treat. All people benefit from it. However, those formulae coming from China are always rare. The names of medicinal drugs that are different from Chinese ones are quite innumerable. Thus, even those who make a living with the skill of healing cannot avoid lamenting not being fully equipped [with medicinal drugs]. ${ }^{61}$

This passage shows us what kind of medicine was claimed to be the most appropriate for people in the Eastern Kingdom. As the eastern locale had developed its own customs, the principles of medicine could hardly have been universally applied. Aspects of disease exhibited themselves differently in accordance with environmental variations, as did medical treatments. Accordingly, the native medicinal stuff was the best fit for 'our' bodily practice. Moreover, the development of native medicine would eventually save time and money. As a way of compensating for the customary dependence on Chinese materia medica, the author argued for the viewing of medicinal principles from a different perspective: not as universally defined principles but as regionally elaborated ways of life. In this manner, the Eastern Kingdom was conjured up not as a marginalised backwater left behind by medical novelties, but as a unique location for the creation of its own medicinal art.

The significance of this claim is beyond question. But when we look more closely at the structure and sources of Standard Prescriptions of Local Botanicals, it becomes clear that this emphasis on indigenousness does not necessarily imply a radical departure from Chinese medicine. Rather, Standard Prescriptions of Local Botanicals was composed to probe fully into the more advanced or universal body of knowledge. The claim for local medicine was thus not so much a shift toward the independent realm of local knowledge, but rather a strategy by the marginal to relate local knowledge to what was regarded as universal knowledge.

${ }^{61}$ Standard Prescriptions of Local Botanicals (鄉藥集成方, 1433), preface. 
A case in point lies with the sources upon which this compilation relied. Standard Prescriptions of Local Botanicals elaborated on the content and structure of the source texts more fully than Prescriptions of Local Botanicals for Emergency Use (㰾藥救急方), which had only summarised the structure of Collected Commentaries on Classical Materia Medica of the Heavenly Husbandman (本草經集詿, c. 530-57) and Illustrated Classic of Materia Medica (本草 圖經, Song Dynasty). In addition, the 'Local Bencao' (墽藥本草) part followed the main outline of Overview of Proven Materia Medica from the Classics and Histories (經史證類大觀本草, $c .1082$ ). ${ }^{62}$ More to the point, whereas only nine volumes out of 85 actually provided information on local botanicals, the title of the whole was given as Standard Prescriptions of Local Botanicals, suggesting that there would be a full description of locally developed prescriptions. The text was never in popular demand. No record of further publication is found after the Chosŏn court republished the text in 1633. It survives today as no more than a display at a museum or rare books at a national library in Korea. ${ }^{63}$ In sum, the dynasty's compilation of local botanicals was not frequently printed or readily consumed during the fifteenth and sixteenth centuries. Neither did bibliographies of medical formulae and texts that flourished later, between the eighteenth and early twentieth centuries, reference any of these grand compilations. Rather, the most widely circulated printed texts in the eighteenth century were classics of Chinese medicine, the latest texts of materia medica written by a Qing scholar, eclectic formulae extracted from various medical literature, and a secret formula for healthy pregnancy and childbirth.

After King Sŏngjong's reign (1469-94), the state project of promoting local botanicals declined mainly due to the rush of medical literature from Ming China. ${ }^{64}$ The texts became accessible to educated readers via official publication during the early sixteenth century. Kim Tu-jong points out, 'prescriptions using the native medicinal drugs were hardly in use, and the collection of the native medicinal drugs were not encouraged, even left ignored.... The flood of Ming medicine that gradually flourished during the reign of King Sŏngjong has much to do with the decline of indigenous medicine'. ${ }^{65}$ Miki Sakae has related this preference for Ming medicine to the popularity of Neo-Confucianism in the central government of Chosŏn Korea. Consequently, it became more normal and even desirable to read, digest and interpret medical texts

${ }^{62} \operatorname{Kim} 1966$, p. 219.

${ }^{63} \mathrm{Kim}$ 2001, p. 523.

${ }^{64}$ Miki 1963, p. 130. The 'rise and decline' narrative is found not only in Korean medicine but also in Korean science and technology. Regarding this pattern, see Kim Yung Sik 1998, pp. 56-9.

${ }^{65}$ Kim 1966, pp. 263-4. 
from Ming China instead of identifying indigenous knowledge of medicine. Neo-Confucianism provided a milieu for literati in Chosŏn to value textual inquiry into the medical classics, and thereby aspire to the tradition of the Confucian sages. In line with this development, Song-Yuan medical theories related to The Treatise on Cold-Damage Disorders (傷寒論, 196-220) or the innovation of the famous 'Four Masters' became mainstream in Chosŏn Korea because they fit the Neo-Confucian ideal of medicine. ${ }^{66}$ This establishment of a new medical at court saw a decline of interest in local botanicals.

\section{Conclusion}

The rise and fall of local botanicals demonstrates Korea's dual position in consuming medicine at the margins. First and foremost, Koreans aimed to utilise locally available medical resources. However, this turn toward indigenous foundations had to be balanced with Koreans' incessant desire for familiarity with the latest medical discourses and precious medicinal herbs from China. The emergence of local botanicals, hence, should be viewed as a strategy of managing the influx of medical knowledge at the margins. This is one way to accommodate the universal at the periphery where the substance, agent and framework of knowledge cannot be exclusively under the Chosŏn Dynasty's own control. Situated at the margins of a Sino-centric world order, Koreans do not necessitate the establishment of their own knowledge grid. In a sense, the accumulation of medical knowledge in Chosŏn Korea could hardly have been autonomous or independent. Simultaneously, however, it was unavoidable for Korean elites to declare the Chosonn's positionality upon the forms of medical knowledge claiming indigenous difference and a geopolitical identity. Chinese medicine as a textual tradition was regarded as universal, but adopting Chinese medicine to another locale calls for situated moderation. What has to be remembered here is that the claim of local botanicals served as a medium to give meaning for a Korean intellectual project. It does not imply any rigid division between the universal and the local; rather, it alludes to a discerning way of relating the local to the universal.

\section{Bibliography}

Ahn, Sang-woo (An, Sang-wu) 2001, 'The Identification of 'Biyebackyobang,' an Ancient Korean Medical Book of Koryo Period', Sŏjihak yŏn'gu, 22, 325-50.

${ }^{66}$ Miki 1963, p. 176. 
Barnes, Linda L. 2007, Needles, Herbs, Gods, and Ghosts: China Healing and the West to 1848, Cambridge Massachusetts: Harvard University Press.

Cha, Wung-seok (Ch'a, Wung-sǒk) 2005, 'Yang dong chang hwa hu rok and the Korea-Japan Medical Culture Exchange of the Year 1711', Korean Journal of Oriental Physiology and Pathology, 19:2, 1-16.

Clark, Donald N. 1998, 'Sino-Korean Tributary Relations under the Ming', in Twitchett, Denis and Mote, Frederick W. (eds), The Cambridge History of China, vol. 8, New York: Cambridge University Press, 272-300.

Cooper, Alix 2007, Inventing the Indigenous: Local Knowledge and Natural History in Early Modern Europe, New York: Cambridge University Press.

Elman, Benjamin A., Duncan, John B., and Ooms, Herman (eds) 2002, Rethinking confucianism, Los Angeles: Regents of the University of California.

Fan, Fa-ti 2004, British Naturalists in Qing China: Science, Empire, and Cultural Encounter, Cambridge, Massachusetts: Harvard University Press.

Han'guk insamsa pyŏnch'an wiwŏnhoe 2002, Han'guk insamsa (韓國人蔘史), Seoul: Tongil munhwasa.

Hyangyak chipsŏngbang (Standard Prescriptions of Local Botanicals, 墽藥集成方) in The Grand Series of the History of Korean Science and Technology: Medicine (韓國科學技術史資料大系) 1988, vol. 3, Seoul: Yõgang Ch'ulp'ansa.

Hyangyak kugŭppang (Prescriptions of Local Botanicals for Emergency Use, 鄉藥救急方) in The Grand Series of the History of Korean Science and Technology: Medicine (韓國科學技術史資料 大系) 1988, vol. 1, Seoul: Yŏgang Ch'ulp'ans.

Imamura, Tomo 1934-40, Ninjinshi (人䒱史) vols 1-7, Keijō: Chōsen sōtokofu senbaikyoku.

Johannsen, Kristin 2006, Ginseng Dreams: The Secret World of America's Most Valuable Plant, Kentucky: The University Press of Kentucky.

Kim, Daewon (Kim Tae-wŏn) 1998, 'The Growth of Private Medicine in the Eighteenth Century', unpublished MA thesis, Seoul National University.

Kim, Sin-gŭn 2001, Han'guk ŭiyaksa (韓國醫藥事), Seoul: Seoul National University Press.

Kim, Tu-jong 1966, History of Korean Medicine (韓國醫學史 全), Seoul: T’amgudang.

Kim, Yung Sik (Kim Yong-sik) 1998, 'Problems and Possibilities in the Study of the History of Korean Science', Osiris, 13, 48-79.

Kwŏn, Pyŏng-t'ak 1986, Yangnyŏngsi yŏn'gu (藥令市研究), Seoul: Han'guk yŏn'guwon.

Lee, Ki-baik (Yi, Ki-baek) trans. by Wagner, Edward W. with Shultz, Edward J. 1984, A New History of Korea, Seoul: Ilchogak.

Lewis, Martin W. and Wigen, Kären E. 1997, The Myth of Continents: A Critique of Metageography, Berkeley: University of California Press.

Li, Shizhen 1977, Compendium of Materia Medica (本草綱目), Beijing: Renminweishengchubanshe.

Liang, Yongxian 2000, 'Wang Yinglin and his Answer to the Questions of a Korean Physician', Chinese Journal of Medical History (中華醫史雜誌), 30:2, 69-72.

— 2001, 'Yi lin cuo yao (Essentials of Medical Works 醫林撮要), and its Historical Materials of Medical Exchange between China and Korea', Chinese Journal of Medical History (中華醫 史雜誌), 31:1, 17-20.

Miki, Sakae (三木榮) 1963, History of Korean Medicine and of Disease in Korea (朝鮮醫學史及 疾病史), Osaka: Shibun shuppansha.

Mun, Jung-yang (Mun, Chung-yang) 2006, 'Science and Technology in King Sejong's Era; Questioning their Independence from the Chinese Ones', Y̌oksa hakbo, 189, 39-72.

Palais, James B. 1995, 'A Search for Korean Uniqueness', Harvard Journal of Asiatic Studies, 55:2, 409-25.

Raj, Kapil 2007, Relocating Modern Science: Circulation and the Construction of Knowledge in South Asia and Europe, 1650-1900, Basingstoke [England], New York: Palgrave Macmillan. 
Shin, Dong Won (Sin, Tong-wŏn) 2002, 'Hyangyak ŭisur i ingu rŭr chŭngga sik'yŏssŭrkka', Yǒksa pip’yong, 61, 251-64.

Yang, Jeong-pil (Yang, Chŏng-p’il) and Yeo, In-sok (Y̌̌, In-sǒk) 2003, 'A Study on the True Nature of Chinese Ginseng', Korean Journal of Medical History, 12, 144-66.

Yi, T’ae-jin 2003a, Üisur kwa ingu kŭrigo nongŏp kisur-Chosŏn yugyo kukka ŭi kyŏngje palchŏn moder, Seoul: T'aehaksa.

2003b, 'Ohae wa yihae pujok ŭi chipchung punsŏk', Y̌oksa pip’yỏng, 62, 225-34.

Zhao Xuemin 1983, Textual Traces of Compendium of Materia Medica (本草綱目拾遺), Beijing: Renminweishengchubanshe.

Zhuang, Zhaoxiang (莊兆祥) 1983, An Introduction to bencao Study (本草砰究入門), Xianggang: Zhongwen daxue chubanshe. 